are very full of blow-holes. They however assert that, notwithstanding the blow-holes, the castings are twice as strong as similar ones made of cast iron. There is considerable waste in making small castings of this steel, and they are therefore obliged to charge heavily for those made, but, as a general thing, they decline to make very small ones at any price. The castings should, if possible, be worked under a hammer. Castings of ordinary cast stcel can be secured at Pittsburg and Jersey City. The Bessemer steel is not intended to take the place of, or compete with, ordinary cast stcel, the properties of the two being quite different in several respects. $\Lambda$ t Troy they are preparing to make stecl rails for railroads, and in Vermont a company is establishing works to manufacture stecl locomotive tires.-D.V.W.

Univority of Hichigan.

\title{
DRILLING MACHINES AT THE HOOSAC TUNNEL,
}

\section{Ann Arbor, Michigan.}

Early in June last, I visited Iloosac Tunnel to witness the operation of the power-drills. Machines have been introduced at the east heading only, where they work eight at a time. These are driven by compressed air, at a pressure of thirty pounds per square inch. The air is compressed by water-power, supplied by the Deerfield river. In the tunnel are two heavy frames or carriages, to each of which are mounted four machines. When I observed them, they made about 180 strokes per minute, and drilled an inch and a half hole about three-fourths of an inch per minute. They may be worked more rapidly at a higher pressure of the motor. All the movements of this machine are automatic, except the advance feed. It appeared to require the constant attendance of a man to see that it did not feed too fast. It secms that this part of the problem has troubled most inventors of drilling machines. They have either failed to make them automatic and self-adjusting, or else the devices have been so costly and delicate, that they were of little practical value. But Professor Robinson (my assistant in the University) and myself have invented a method which, we think, entirely overcomes the difficulty. It is cheap, strong, simple in its structure, and perfectly automatic and self-adjusting. It will feed four or five inches at a stroke, if necessury; but, if the cutting does not advance, it will not feed any. If the other parts of a drilling machine can be made as strong and simple as this, no further difficulty will be experienced with them. 
Several machines have been tried in the tunnel, but all have failed, except the one now being used. Massachusetts expended about $\$ 13,000$ in experimenting upon these machines, which resulted in the construction of the Brooks, Burleigh \& 'Gates' machine, which promised well at first, but which was cast aside after five or six months' trial. They broke so rapidly that they could not keep a supply in the tunnel, and at one time there was only one at work. The machine which they are now using (Burleigh's) is a great improvement over all others tried, so far as breakago is concerned. A few men in the repair shop can keep them in running order, and they can do more work with them.

The failure of so many machines was casting a doubt over the minds of many about the success of drilling machines, and the question of abandoning them at present, and resorting to hand-labor only, was seriously discussed. This doubt was strongly entertained by the consulting engineer, Mr. Latrobe, (see Report of the Commissioners, House Doc., No. 30, p. 57.) He advised their removal and a resort to hand-labor, but recommended that experiments be made outside the tunncl. But, fortunately for science, as well as for the advanccment of this particular work, the use of the machines has been continued, and they are now making nearly double the advance ever made by hand-labor. The average advance, for several months in 1865-66, by hand-labor, was $55 \frac{1}{4}$ feet per month. When I was there, they were advancing at the rate of nearly 100 feet per month with machines. I doubt not they will yet make more rapid progress. In Mont Cenis-the great Italian tunnel-they have advanced at the rate of 7 feet per day, or 162 fect per month of 26 days. In that tunnel they do not observe the Sabbath, and hence they inakc over 200 feet monthly. But such a rate cannot be expected in Hoosac, on account of the peculiar character of the dip of the rock. The rock is friable, and the blast does not throw out a very largo quantity, considcring the number and depths of the holes.

Mr. Latrobe says (page 56) that the rapid blow of machine drills tends to heat the bit, and, by injuring its temper, causes it to wear much faster than hand-drills. This appears very plausiblo; and yet, from my own experiments and the statistics of others, I am satisfied that drills will do more work in a machine, without sharpening, than they will by hand, and, if water be used in both cases, there is a very great advantage in favor of machine-drills. In the Report of the Chief Engineer, Mr. Doane, on page 30 of the doct- 
ment above referred to, we find that, with hand-labor, for one foot of advance, there were 280 drills dulled and 638 inches of hole; and, on page 31 , for one foot of advance, with machines, there were 48 drills dulled and 843 inches of hole-showing that, for every foot of alvance, it takes $5_{10}^{\mathrm{s}}$ times as many drills by hand as by machines; also, that the machine-drills made $7_{10}^{8}$ times as many inches as the hand-drills, without sharpening. At the east heading is the only place where both machines and hand-labor have been used, or at least there is no other data in said report from which an exact comparison can be made; but the statistics of the work on the central shaft lead us to infer that similar results might be expected there from the use of machines. At the east heading, hand-drills dulled, on an average, evcry 2.24 inches, but in the central shaft (p. 35), every 3.30 inches, and, still later (p. 37), 4.51 inches-the last two of which is but little more than half the average by machines. The rock is more easily drilled at the central shaft (p. 62).

It should also be said, in favor of the machine-drills, that the above data is taken from the work of the old machines, which were rejectcd about the time that the report was made. I was told by the superintendent of the shop, Mr. Hall, that, with the device for holding the drills which was used in that machine, it cost them $\$ 20$ per day to kcep the drills in the machine. The drills would get loose and break, but the device which they now use holds the drills firmly and they have no trouble to keep them in their place, so that the average distance which the drill will cut in the improved machine should be considerably greater than that given above for the old machines. We ought to expect this result. All tools, or rather machines, when properly constructed, do more work than hand tools without sharpening or repairing. As cxamples, witness the machines for planing, morticing, sawing, nail-cutting, sewing, weaving and mowing. The repairs may cost more when made. I have seen a mowing machine cut acres without sharpening, where the scythe should be sharpened many times, and do more work without repairing than scythe and snath. As a general thing, machines which will not do this cannot compete with hand-labor, and cannot come into general use.

A heavy contract has just been made with Dull \& Gowan, the contractors of the Chicago tunnel, involving over a million of dollars. They are to extend the heading at the east end at the rate of 91 feet per month, and enlarge the whole tunnel for over 6000 feet, and sink the central shaft to grade (about 540 feet), at the rate of 30 feet per 
month. With these conditions, their contract extends two years, There is also a contract at the west end, but I think that the west shaft is still under the supervision of the State. Should the experinents now being made by Professor Robinson and myself prove suceessful, we hope to put a machine into the tunnel that will considerably hasten the progress of the work.

DE VOLSON WOOD.

University of Michigan, July, 1867.

\section{THE COMPOSITION OF MORTAR.}

True following communication, which we have just received from Mr. E. F. Moody, is of especial interest, because it serves to correct a statement which has received the sanetion of high authority and very general acceptanes. Thus, Graham states in his Chemistry, - p. 408 of the Philadelphia cdition, that "The mortar is sulject to an ulterior change from the slow absorption of carbonic acid, but cven in the oldest mortar the conversion of the hydrate of lime into carbonate is never complete." Similar statements are to be found in many other works.-Ev.

\section{Pimladelpmia, July 20th, 1867.}

Prof. Henry Morton, Ph.D.

DenR Srr: Recently a committee of Councils of a neighboring city, contemplated the erection of a large building, and among the materials offered was an artificial stone. The low cost of the article induced the Committce to examine it with great care, and to visit New York where it has been used.

Of course, the principal question was the all-important one of durability, and in order to gain a comparative idea of this, it was necessary to bo satisfied as to the true theory of the hardening of compositions of lime and sand, or mortar, whether caused by mechanical or chemical agency. If chemical, the hydrate of lime must slowly absorb carbonic acid from the air, and form carbonate of lime, a material of the requisite stability. I consulted Graham and other leading works, but could not find anything satisfactory. I therefore made the following examinations:

By the first scries of experiments, it was proposed to determine whether mortar does or does not absorb carbonic acid. I placed in an appropriate apparatus, one hundred and twenty grains of pulver- 